\title{
Activated Carbon from the Peelings of Cassava Tubers (Manihot esculenta) for the Removal of Nickel(II) Ions from Aqueous Solution
}

\author{
Brice Armel Ajouafeu Alongamo, ${ }^{1}$ Lydie Dodo Ajifack, ${ }^{1,2}$ Julius Numbonui Ghogomu $\mathbb{D}^{1,2}$ \\ Ndi Julius Nsami, ${ }^{3}$ and Joseph Mbadcam Ketcha ${ }^{3}$ \\ ${ }^{1}$ Department of Chemistry, Faculty of Science, University of Dschang, P.O. Box 67, Dschang, Cameroon \\ ${ }^{2}$ Department of Chemistry, Faculty of Science, the University of Bamenda, P.O. Box 39 Bambili, Bamenda, Cameroon \\ ${ }^{3}$ Department of Inorganic Chemistry, Faculty of Science University of Yaoundé 1, P.O. Box 812, Yaounde, Cameroon
}

Correspondence should be addressed to Julius Numbonui Ghogomu; ghogsjuju@hotmail.com

Received 8 February 2021; Revised 26 June 2021; Accepted 22 July 2021; Published 2 August 2021

Academic Editor: Marcelino Maneiro

Copyright (C) 2021 Brice Armel Ajouafeu Alongamo et al. This is an open access article distributed under the Creative Commons Attribution License, which permits unrestricted use, distribution, and reproduction in any medium, provided the original work is properly cited.

\begin{abstract}
Activated carbons were obtained from the peelings of cassava tubers (Manihot esculenta) by chemical activation using potassium hydroxide and phosphoric acid at impregnation ratios of $2: 1$ and $1: 1$, respectively, at $400^{\circ} \mathrm{C}$ for batch adsorption of nickel(II) ions from aqueous solution. Characterization of activated carbon samples was achieved via proximate analysis, Fourier-transform infrared spectroscopy, $\mathrm{pH}$ of zero-point charge, Boehm method, elemental analysis, scanning electron microscopy, and iodine number determination for each adsorbent. The effects of $\mathrm{pH}$, contact time, initial adsorbate concentration, and adsorbent dose were studied at $27^{\circ} \mathrm{C}$ in order to optimize the conditions for maximum adsorption. Equilibrium was attained after 40 minutes of contact of both materials with activating solutions. Maximum adsorption capacities of $41.15 \mathrm{mg} / \mathrm{g}$ for ACPH, $47.39 \mathrm{mg} / \mathrm{g}$ for ACPA, $35.34 \mathrm{mg} / \mathrm{g}$ for NIC, and $34.48 \mathrm{mg} / \mathrm{g}$ for RM, respectively, were obtained at $\mathrm{pH}=4$. Equilibrium data showed that the Langmuir model best described the adsorption process with $R^{2}$ closed to unity, indicative of monolayer adsorption on a homogeneous surface. Kinetic studies showed that the adsorption process is controlled by the pseudo-second-order model. These results show that activated carbon prepared from cassava peelings constitutes an effective low-cost material for the treatment of wastewater containing nickel(II) ions.
\end{abstract}

\section{Introduction}

Pollution by heavy metals is a global health and environmental concern [1]. Nickel is a nonbiodegradable and toxic heavy metal, which is ubiquitous in wastewater bodies in various proportions [2]. The main origin of nickel pollution in water is from industrial processes such as galvanization, smelting mining, dyeing operation, battery manufacturing, and metal finishing [3]. Trace amounts of nickel are beneficial to human life as enzyme activators. Above permissible concentrations (toxic limits) of nickel of $0.1 \mathrm{mg} / \mathrm{m}^{3}$ (World Health Organization (WHO)) [4], different types of diseases may be contracted such as lung cancer, renal edema, dermatitis, and gastrointestinal disorder. Conventional methods for nickel(II) removal from wastewater include chemical oxidation or reduction, chemical precipitation, ion exchange, membrane separation, filtration, electrochemical treatment, and adsorption [5]. These techniques which are economically expensive suffer from incomplete metal removal, generation of toxic sludge, and other disposable waste products [6]. Adsorption techniques using organic, inorganic, natural, synthetic, activated, or modified adsorbents are the most widely employed procedures in wastewater treatment and constitute low-cost alternatives. From the literature survey, potential low-cost adsorbents (activated or not) for heavy metal removal include the following: 
Rice Husk [4], sugarcane bagasse pith [7], coconut husk, date stones, teak tree bark [8], palm fruit seeds [9], exhausted olive cake, coconut leaves, ion exchange resins [10], industrial wastes [11], fruit wastes, sugar industry wastes, seafood-processing wastes, wood-type materials, petroleum wastes, and fertilizer wastes [12]. Activated carbon is obtained via either physical or chemical activation procedures and is characterized by a large surface area, high adsorption capacity, high yields, porous structure, selective adsorption, and high purity [13]. During the chemical activation process, reagents such as inorganic salts $\left(\mathrm{ZnCl}_{2}, \mathrm{FeCl}_{3}, \mathrm{KHCO}_{3}\right.$, $\mathrm{NaCl}, \mathrm{MgCl}_{2}, \mathrm{Na}_{2} \mathrm{CO}_{3} \mathrm{CaCl}_{2}$, and $\left.\mathrm{K}_{2} \mathrm{CO}_{3}\right)$, acids $\left(\mathrm{HNO}_{3}\right.$, $\mathrm{H}_{2} \mathrm{SO}_{4}$, and $\left.\mathrm{H}_{3} \mathrm{PO}_{4}\right)$, or soluble bases $(\mathrm{NaOH}, \mathrm{KOH})$ are often used [14]. These chemical agents favor the dehydration of materials and allow for the development of micropores [15]. The objective of this study was to evaluate the performance of activated carbons obtained by chemical activation with $\mathrm{KOH}$ and $\mathrm{H}_{3} \mathrm{PO}_{4}$ of the peelings of cassava tubers (Manihot esculenta) for the removal of nickel(II) from aqueous solution.

\section{Materials and Methods}

2.1. Collection and Pretreatment of Raw Materials. In order to valorize low-cost local materials like activated carbon, the Forastero variety of cassava tuber peelings (Manihot esculenta) was used as a precursor because of its abundance in the subregion. Cassava tuber peelings were acquired in great quantity from a local factory in Santchou village situated in the West Region of Cameroon which is involved in the processing of cassava-based foodstuff. They were transported to the laboratory after undergoing thorough washing and cleaning under tap and distilled water for the removal of residual soil and other impurities. In the laboratory, they were stripped of their outer thin skin with a plastic brush, chopped into smaller pieces, and air dried for two weeks after which they were crushed in a mill and finally sieved to have the coarse grain fraction with average particle size of $2 \mathrm{~mm}$ (with increased surface area for activation). The dried peelings underwent coarse crushing in order to obtain homogeneous materials (precursors). After sieving through standard steel sieves, only fractions with diameters of less than $400 \mu \mathrm{m}$ were retained (Figure 1).

2.2. Production of Activated Carbon. In this study, all chemicals used for activation purposes were of analytical grade. Test samples were prepared in two ways: the first part involved the chemical activation process involving phosphoric acid $\left(\mathrm{H}_{3} \mathrm{PO}_{4}\right.$, from Fischer Scientific International at $85 \%$ purity) and potassium hydroxide $(\mathrm{KOH}$, from Fischer Scientific International at $87.90 \%$ purity) as activation agents. This method consisted of mixing the precursor material with either $10 \%$ weight of $\mathrm{KOH}$ (activated carbon, potassium hydroxide $(\mathrm{ACPH})$ ) or $10 \%$ weight of $\mathrm{H}_{3} \mathrm{PO}_{4}$ (activated carbon, phosphoric acid (ACPA)) before carbonization. $10.0 \mathrm{~g}$ of material samples was impregnated with solutions of activating agent $\left(\mathrm{KOH}\right.$ and $\left.\mathrm{H}_{3} \mathrm{PO}_{4}\right)$ in a desired weight ratio of material to the activating agent of $2: 1,1: 1$, and $1: 2$, respectively. The impregnated samples were then placed in an oven at $110^{\circ} \mathrm{C}$ for 24 hours. In the second part, samples were prepared in the same manner but without impregnation or activation. Both the treated and untreated samples were later carbonized for one hour in a Carbolite furnace (Heraeus) in the absence of air (oxygen). Initially, the furnace was heated to temperatures of 300,400 , and $500^{\circ} \mathrm{C}$, respectively, at a heating rate of $10^{\circ} \mathrm{C} \mathrm{min}^{-1}$ for 1 hour (activation time). The variation of these activation and calcination parameters is summarized in Table S1 of supplementary materials. The carbonized samples were then allowed to cool to ambient temperature. ACPA samples after washing abundantly with distilled water were treated with lead nitrate $(0.1 \mathrm{M}$ ) (from BDH Chemicals Ltd. at $98 \%$ purity) in order to ensure the complete elimination of traces of phosphate ions. ACPH samples on their part were then leached with a solution of hydrochloric acid $(\mathrm{HCl} 0.1 \mathrm{M}$ (from Prolabo at $36 \%$ purity)) for 2 hours and abundantly washed with distilled water until the $\mathrm{pH}$ of the resulting samples ranged between 6 and 7. Silver nitrate (from Alfa Aesar at $99.9 \%$ purity) test was conducted to check for complete elimination of the chloride ions introduced [14]. The resultant activated carbon samples (ACPH, ACPA) and the nonimpregnated carbon (NIC) along with precursors (raw material (RM)) were then oven-dried at $110^{\circ} \mathrm{C}$ for a period of 24 hours, ground, and then sieved to obtain particles with diameters less than $100 \mu \mathrm{m}$. The preparation steps are as indicated in Figure 1.

2.3. Proximate Analysis. Proximate analysis is a series of tests used for the determination of the composition of available macronutrients (moisture content, volatile matter, ash content, and fixed carbon content) in the cassava tuber peelings when samples were heated and treated under specific conditions.

2.3.1. Moisture Content. The moisture content of the material samples was determined according to the procedure established by the American Society for Testing and Materials (ASTMD 2867-99) [16] in which $1.0 \mathrm{~g}$ of dried material was weighed in a cleaned crucible and was oven-dried at $110^{\circ} \mathrm{C}$ for 3 hours. After drying, samples were then cooled at room temperature in a desiccator and reweighed in order to determine their moisture contents according to the following equation:

$$
\text { moisture content }(\%)=\frac{\text { loss in weight in drying }(g)}{\text { initial sample weight }(g)} \times 100 \text {. }
$$

2.3.2. Ash Content. The ash content of the material samples was determined via the ASTMD 2867-94 standard method [16] in which $1.0 \mathrm{~g}$ of dry sample was weighed inside a crucible, oven-dried at $105^{\circ} \mathrm{C}$, and later introduced into a Carbolite furnace (Heraeus) that was then heated to $600^{\circ} \mathrm{C}$ at a heating rate of $10^{\circ} \mathrm{C} \mathrm{min}^{-1}$ for 1 hour. The carbonized sample was then allowed to cool to ambient temperature. 

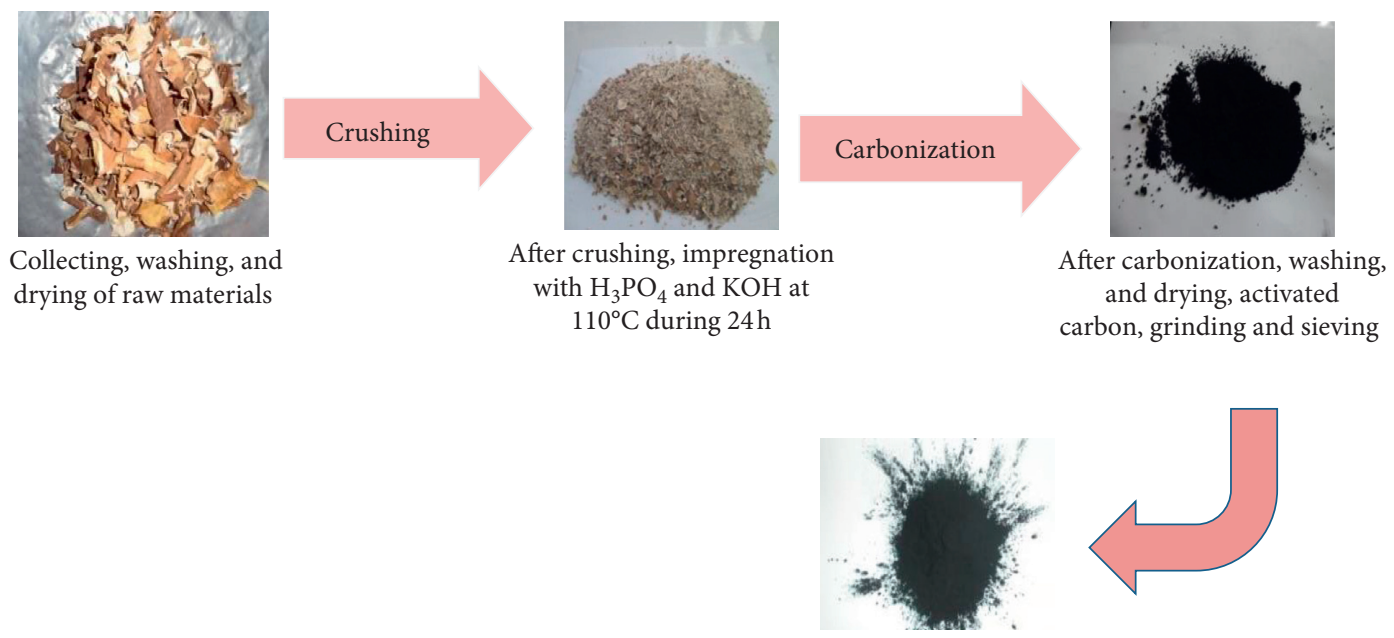

FIGURE 1: Step-by-step illustration of AC preparation from the peelings of cassava tubers.

The samples were then removed from the furnace and stored in a desiccator. The sample was then reweighed, and the ash content was obtained from the difference in weight according to the following equation:

$$
\text { ash content }(\%)=\frac{\text { weight of ash }(g)}{\text { oven dry weight }(g)} \times 100 \text {. }
$$

2.3.3. Volatile Matter. Volatile matter of the material samples was determined via the ASTMD 2867-99 standard method [16] in which $1.0 \mathrm{~g}$ of dry sample is weighed inside a crucible and oven-dried at $105^{\circ} \mathrm{C}$ and then heated to $600^{\circ} \mathrm{C}$ for 1 hour in a Carbolite furnace (Heraeus) at a heating rate of $10^{\circ} \mathrm{C} \mathrm{min}$. The carbonized sample was then allowed to cool to ambient temperature and later was removed from the furnace and stored in a desiccator. The sample was then reweighed, and the volatile matter was calculated from the difference in weight according to the following equation:

$$
\text { volatile matter }(\%)=\frac{\text { weight of volatile component }(g)}{\text { oven }- \text { dry weight }(g)} \times 100 \text {. }
$$

The fixed carbon content was obtained by subtracting the percentage of moisture, ash, and volatile matter content of the materials from a hundred percent according to

$$
\begin{aligned}
& \text { fixed carbon }(\%)=100 \text { - moisture (\%) } \\
& \text {-ash content }(\%) \text { - volatile matter (\%). }
\end{aligned}
$$

2.4. Iodine Number (IN). The iodine number (IN) is a relative indicator of porosity in activated carbon. The iodine number was measured according to the procedure established by the American Society for Testing and Materials (ASTM D2866-94) [17]. It is the number of milligrams of iodine adsorbed by $1.0 \mathrm{~g}$ of carbon when the iodine concentration of the filtrate is $0.02 \mathrm{~N}$. The iodine number is accepted as a fundamental parameter used to characterize activated carbon performance. Iodine number was employed in this study as a test for microporosity via volumetric analysis. This fundamental ability test for activated carbon determines its microporosity to $\leq 2 \mathrm{~nm}$.

2.4.1. Standardization of Iodine Solution. $10 \mathrm{~mL}$ of $0.02 \mathrm{~N}$ iodine solutions (from Merck at $99.95 \%$ purity) was measured and put into a conical flask, and 2-3 drops of a starch solution were added to it. The pale-yellow color of the iodine solution turned blue and was titrated against a $0.005 \mathrm{~N}$ sodium thiosulphate solution (from Fischer Scientific International at 99.8\%) until the mixture became colorless.

2.4.2. Determination of Iodine Number. $0.1 \mathrm{~g}$ of activated carbon was weighed (mAC) and carefully introduced into a dry screw cap conical flask. $30 \mathrm{~mL}$ of $0.02 \mathrm{~N}$ iodine solutions was then added. The flask was magnetically stirred for 3 hours, and the content was filtered into a dry conical flask. Then, $10 \mathrm{~mL}$ of the filtrate was titrated against sodium thiosulphate solution $\left(5 \times 10^{-3} \mathrm{M}\right)\left(\mathrm{Na}_{2} \mathrm{~S}_{2} \mathrm{O}_{3}\right.$ from Acros organics at $99 \%$ purity) using starch as indicator until a clear solution was observed according to equation (5). The volume delivered by the burette was then noted $\left(V_{n}\right)$. The iodine number for the sample was then calculated according to equation (6):

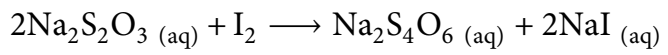

$$
\begin{aligned}
& \text { iodine number }=\frac{25.4 \times\left(30-V_{n}\right)}{m_{\mathrm{AC}}},
\end{aligned}
$$

where $m_{A C}(g)$ is the mass of the activated carbon and $V_{n}$ $(\mathrm{mL})$ is the volume of the sodium thiosulphate solution at the equivalence point. 


\section{Characterization of Adsorbents}

3.1. Determination of Oxygen Containing Functional Groups. The determination of the total surface acidity and basicity of the activated carbons was carried out via the Boehm method $[18,19]$. Acidic surface functions (carboxylic, lactonic, phenolic) were determined by adding $40 \mathrm{~mL}$ decimolar solution of $\mathrm{NaHCO}_{3}$ (from Fischer Scientific International at 99.7\%), $\mathrm{Na}_{2} \mathrm{CO}_{3}$ (from Fischer Scientific International at 99.8\% purity), and $\mathrm{NaOH}$ (from Fischer Scientific International at 99.5\%) into different reactors, each of which previously contained $0.1 \mathrm{~g}$ of activated carbon sample. Titration of the excess base was done by using a decimolar solution of $\mathrm{HCl}$ after stirring for 48 hours. In the determination of basic functions, $0.1 \mathrm{~g}$ of activated carbon was added to $40 \mathrm{~mL}$ of a decimolar solution of $\mathrm{HCl}$. After stirring for 48 hours, the excess acid was titrated with a decimolar solution of $\mathrm{NaOH}$.

3.2. Determination of $p H$ at Zero-Point Charge ( $p H z p c)$. The $\mathrm{pH}$ at a zero-point charge ( $\mathrm{pHzpc}$ ) corresponds to a $\mathrm{pH}$ at which the surface charge of activated carbon is neutral. pHzpc of the activated carbon samples was estimated according to the standard procedure [20,21]. $40.0 \mathrm{~mL}$ of a decimolar solution of $\mathrm{NaCl}$ (from Fischer Scientific International at $99.5 \%$ ) was introduced into reactors each containing $0.1 \mathrm{~g}$ of activated carbon to be analyzed. The $\mathrm{pH}$ of each solution was then adjusted by the addition of decimolar solutions of $\mathrm{NaOH}$ or $\mathrm{HCl}$ (by varying values of $\mathrm{pH}$ between 2 and 12). pHzpc was determined by the intersection of the representative curves $\mathrm{pH}($ final $)=f(\mathrm{pH}$ (initial) $)$ and the first bisector curve. Stirring was maintained at $27^{\circ} \mathrm{C}$ for 48 hours with the aid of a multiagitator system (Edmund BühlerGmbH) and at $150 \mathrm{rpm}$. The contents of the reactors were then filtered with Whatman filter paper $\mathrm{N}^{\circ} 4$ after which the $\mathrm{pH}$ of the final solutions was measured.

3.3. Analysis by Fourier-Transform-IR Spectrophotometer (FTIR). Surface functional groups of adsorbents and their transformation after activation were analyzed using an infrared spectrophotometer (Brüker alpha-p spectrometer) with ethanol (from Fischer Scientific International at 98\%) as a solvent with a resolution of $4 \mathrm{~cm}^{-1}$ within the interval $400-4000 \mathrm{~cm}^{-1}$.

3.4. Scanning Electron Microscopy (SEM) Analysis. Surface morphology and adsorbent porosity of activated carbon samples were examined by a scanning electron microscope (SEM' ${ }^{\prime}$ PHILIPS XL30 S-FEG) equipped with a spectrometer having a cathode luminescence detector. These were achieved by the juxtaposition of SEM images of precursor samples (RM) with those of the activated carbon (ACPH, ACPA, and NIC). Only the precursor and the activated carbon samples with high iodine numbers were chosen for SEM analysis.
3.5. Elemental Analysis. Elemental composition (C, H, N, S, and $\mathrm{O}$ ) of $\mathrm{ACPH}, \mathrm{ACPA}, \mathrm{NIC}$, and $\mathrm{RM}$ at $400^{\circ} \mathrm{C}$ was obtained using an elemental analyzer (Thermo Scientific FLASH 2000).

\section{Equilibrium Studies via Batch Adsorption}

4.1. Preparation and Determination of Nickel(II) Ions. A standard $2000 \mathrm{mg} / \mathrm{L}$ mother solution of nickel(II) was prepared by dissolving $2.1 \mathrm{~g}$ of $\mathrm{AR}$ grade nickel chloride hexahydrate $\left(\mathrm{NiCl}_{2} \cdot 6 \mathrm{H}_{2} \mathrm{O}\right)$ of molar mass $(M=237.71 \mathrm{~g} / \mathrm{mol}$ at $98.6 \%$ purity from Fischer Scientific International) inside a $250 \mathrm{~mL}$ volumetric flask. $5 \mathrm{~mL}$ of a $1 \% \mathrm{HNO}_{3}$ (from Merck at $65 \%$ purity) was immediately added to it. Then, the contents were made up to the mark with distilled water and homogenized for 1 hour. Successive dilution of the mother solution gave rise to the working solutions.

4.2. Analysis of Nickel(II). Nickel(II) was estimated spectrophotometrically using dimethylglyoxime (DMG, from Fischer Scientific International) solution [22]. Different working solutions containing less than $300 \mathrm{mg} / \mathrm{L}$ of nickel(II) were prepared by dilution. To each given nickel filtrate was added with $2 \mathrm{~mL}$ of $4 \% \mathrm{w} / \mathrm{v}$ potassium persulphate $\left(\mathrm{K}_{2} \mathrm{~S}_{2} \mathrm{O}_{8}\right.$, from Prolabo at $100 \%$ purity) and allowed to react for 10 minutes. Then, $4 \mathrm{~mL}$ of ammonia (4 M) (from Fischer Scientific International at $87 \%$ purity) and $0.5 \mathrm{~mL}$ of DMG $(10 \% \mathrm{w} / \mathrm{v})$ were also added. The absorbance of the mixture was measured after 30 minutes using a UV-visible spectrophotometer (JENWAY) at $465 \mathrm{~nm}$.

4.3. Equilibrium Studies Using Batch Method. Kinetic and equilibrium studies of nickel(II) adsorption were carried out in a thermostatic batch reactor maintained at $27^{\circ} \mathrm{C}$. In each measurement, $0.1 \mathrm{~g}$ of adsorbent was introduced into a $20 \mathrm{~mL}$ beaker containing nickel(II) solution which previously underwent $\mathrm{pH}$ adjustment by addition of $0.1 \mathrm{~N}$ solution of $\mathrm{HCl}$ or $\mathrm{NaOH}$. The effect of the adsorbent dose was carried out at $\mathrm{pH} 4$ with an initial metal ion concentration of $240 \mathrm{mg} / \mathrm{L}$ and varying the adsorbent dose from $0.1 \mathrm{~g}$ to $0.6 \mathrm{~g}$. The effect of $\mathrm{pH}$ on the adsorption of nickel(II) ions was investigated by varying the $\mathrm{pH}$ of the equilibrium solution from 2 to 8 (using Hannah Instruments). In kinetic studies, the different mixtures were stirred within a time interval between 5 and 60 minutes for equilibrium time determination. After filtration of trial solutions with Whatman filter paper No. 4, the residual nickel(II) ion concentration in each sample was determined by UV-visible spectrophotometer (JENWAY) at $465 \mathrm{~nm}$ wavelength. The sorption capacity of samples at equilibrium $\left(Q_{e}\right)$ and the percentage removal (\%R) are given by (7) and (8).

$$
\begin{aligned}
Q_{e} & =\frac{\left(C_{0}-C_{f}\right) V}{m}, \\
\% R & =\frac{\left(C_{0}-C_{f}\right) \times 100}{C_{0}},
\end{aligned}
$$


where $v$ is the volume of nickel, $m$ is the sample mass, and $C_{0}$ and $C_{f}$ are the initial and final concentrations of nickel, respectively.

4.4. Nonlinear Regression Analysis. In this study, nonlinear regression was applied using the Microsoft Excel Solver function and using Origin Pro 9, 64 bit for fitting the curve. The best fit for experimental data was determined from the regression coefficient $\left(R^{2}\right)$ and residual root mean square error (RMSE). More detailed definitions of the error functions and statistical comparison values are presented in Table 1.

\section{Results and Discussion}

5.1. Proximate Analysis. The results of the proximate analysis for the determination of macronutrients of cassava peelings are presented in Figure 2 which shows 1\% moisture content, $8 \%$ ash content, $13 \%$ volatile matter, and $78 \%$ of fixed carbon. It can be seen here that the materials are good precursors for the production of activated carbon [16].

5.2. Elemental Analyses. The results of the elemental composition of investigated precursors and activated carbons carbonized at $400^{\circ} \mathrm{C}$ are given in Table 2. Results show higher proportions of carbon and oxygen in the precursor (RM) than of hydrogen and nitrogen, confirming the organic and acidic nature of the materials. We also observe a considerable reduction in oxygen content and a slight increase in nitrogen content after the activation/calcination process, thus confirming the acidic nature of the precursor and the acid-base nature of the different carbon materials. The activated carbons obtained are very rich in acid-base surface functions. Carbon content increases as one passes from precursor to the different activated carbons prepared (ACPH, ACPA, and NIC). This means that calcination/ carbonization of precursor facilitates the liberation of volatile entities such as hydrogen [25].

\subsection{Effect of Calcination Temperature on the Iodine Number.} Figure 3 shows that as temperature increased from $300^{\circ} \mathrm{C}$ to $400^{\circ} \mathrm{C}$, the iodine number increased as well for ACPA, $\mathrm{ACPH}$, and NIC samples. The main reason for this increase is the development of micropores on the adsorbent surface, thus increasing their adsorption capacity [26]. But beyond $400^{\circ} \mathrm{C}$, the iodine number decreased as a result of the destruction of formed micropores and consequently a sharp decrease in their adsorption capacity [26]. It can be observed from these results that iodine number reached its maximum value at $400^{\circ} \mathrm{C}$ for $\mathrm{ACPA}, \mathrm{ACPH}$, and NIC with optimal iodine numbers of $523.46,618.64$, and $492.17 \mathrm{mg} / \mathrm{g}$, respectively, indicative of microporous activated carbon according to ASTMD 2866-94 norms [17].

\subsection{Characterization of Adsorbents}

5.4.1. Determination of Oxygen Containing Functional Groups. Boehm titration was used to determine oxygenated surface groups [19]. Table 3 shows results of quantitative surface chemical analysis (amount of acidic and basic functional groups on ACPH, ACPA, NIC, and RM). These results show that the three activated carbon samples contain more basic than acidic (carboxylic and phenolic groups) functions. On the contrary, precursor samples showed more acidic (carboxylic and phenolic groups) than basic due to a decrease in the number of lactonic functions. This observation is in conformity with the $\mathrm{pH}_{\mathrm{PZC}}$ values which are proportional to the acidic and basic functions.

5.4.2. Determination of $p H$ at Zero-Point Charge ( $p H z p c)$. $\mathrm{pHzpc}$ values indicate the acidic or basic character of samples and their net surface charges. Knowledge of pHzpc helps to predict the type of interactions that take place during the adsorption process. The $\mathrm{pHzpc}$ obtained for each activated carbon and for the peelings of cassava tubers (Figure 4) is coherent with the quantification of the surface functional groups obtained via the Boehm method. According to Figure 4, the values of the pHzpc obtained are 8.0, 7.8, 7.3, and 6.3 for ACPH, ACPA, NIC, and RM adsorbents, respectively. Hence, in these experiments and for $\mathrm{pH}<\mathrm{pHzpc}$, samples will have their surfaces positively charged while those for which $\mathrm{pH}>\mathrm{pHzpc}$ will have their surfaces negatively charged.

5.4.3. Fourier-Transform Infrared Spectroscopy (FTIR). The results of FTIR analysis for the peelings of cassava tuber samples are depicted in Figure 5. After activation of the peelings of cassava tubers powder, a comparison of the different spectra of the products obtained with that of the biomass was made in order to measure the effects of activation and the modification brought to the surface of the raw material. Figure 5 illustrates these different spectra. The superimposed FTIR spectra of the activated carbons (ACPH, ACPA, NIC, and RM) with the peelings of cassava tubers are shown in Figure 5. Table 4 summarizes the wavenumbers and assignments of the main bands observed in Figure 5.

From the above results obtained from spectral analysis of the activated carbons (ACPH, ACPA, and (NIC), we observe a broad absorption band centered around $3284.84 \mathrm{~cm}^{-1}$ corresponding to $\mathrm{O}-\mathrm{H}$ bond stretching characteristic of phenol, alcohol, or water. We note that this broadband decreases in intensity during the calcination. This is due to the fact that the surface of the material is degraded during the calcination process and thereby causing the departure of the $\mathrm{C}, \mathrm{H}$, and $\mathrm{O}$ atoms in the form of gases $\left(\mathrm{CO}_{2}, \mathrm{CH}_{4}\right.$, and $\mathrm{CO}$ ) and the disappearance of the water molecules [28]. This is further justified by the fact that phosphoric acid and potassium hydroxide being dehydrating agents would react with the raw material, and this will cause the departure of 
TABLE 1: Error functions and their equations.

\begin{tabular}{|c|c|c|c|c|}
\hline Error function & Abbreviation & Formula & $\begin{array}{c}\text { Equation } \\
\text { number }\end{array}$ & References \\
\hline $\begin{array}{l}\text { Residual root mean square } \\
\text { error }\end{array}$ & RMSE & $\sqrt{1 / n-2 \sum_{i=1}^{N}\left(Q_{e, \exp }-Q_{e, c a l}\right)^{2}}$ & (9) & [23] \\
\hline Coefficient of regression & $R^{2}$ & $\sum_{i=1}^{N}\left(Q_{e, c a l}-Q_{e \exp }\right)^{2} / \sum_{i=1}^{N}\left(Q_{e, c a l}-Q_{e \exp }\right)^{2}+\left(Q_{e, c a l}-Q_{e \exp }\right)^{2}$ & $(10)$ & {$[24]$} \\
\hline
\end{tabular}

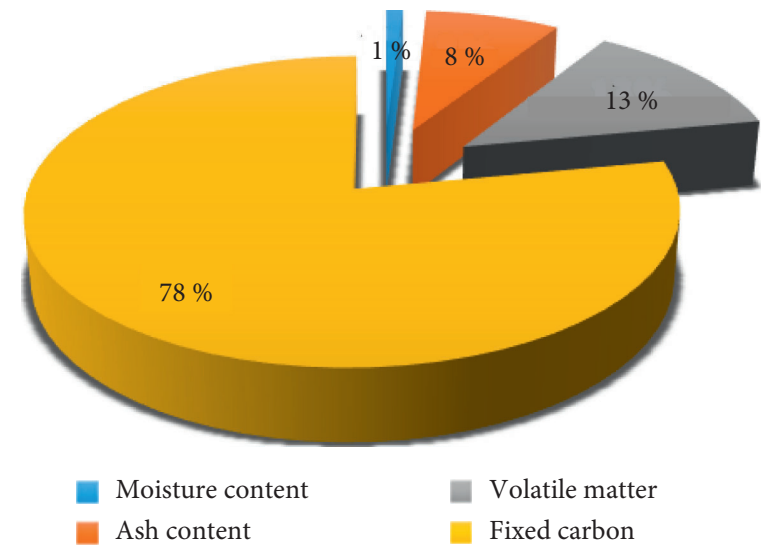

FIGURE 2: The proximate analysis giving the composition of the peelings of cassava tubers.

TABLE 2: Elemental composition (\%) of ACPH, ACPA, NIC, and RM.

\begin{tabular}{lcccr}
\hline Sample & $\% \mathrm{~N}$ & $\% \mathrm{C}$ & $\% \mathrm{H}$ & \\
\hline ACPH & 2.69 & 68.90 & 2.76 & \\
ACPA & 2.64 & 64.52 & 2.11 & \\
NIC & 2.69 & 66.60 & 2.48 & 30.73 \\
RM & 1.23 & 40.57 & 5.99 & 28.23 \\
\hline
\end{tabular}

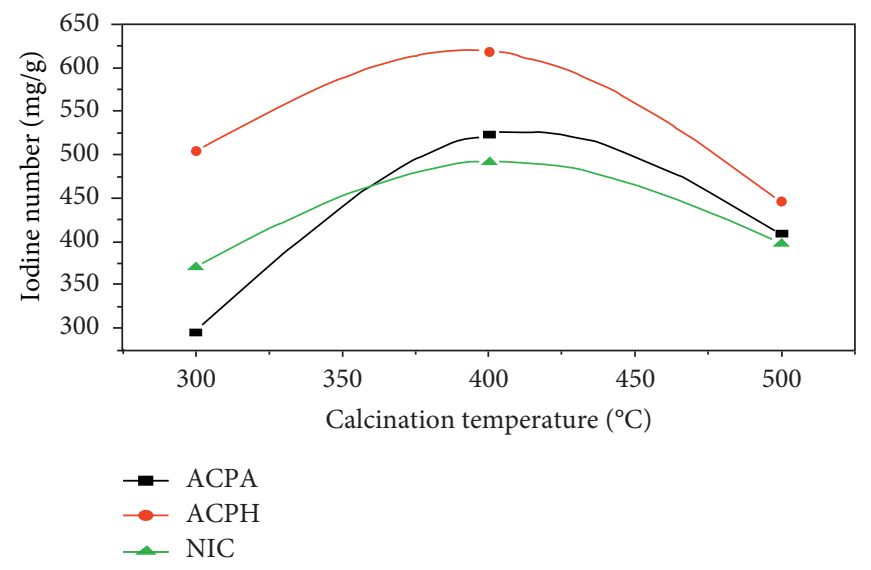

FIGURE 3: Effect of calcination temperature on the iodine number.

TABLE 3: Surface functional groups of precursors and activated carbon from peelings of cassava tubers.

\begin{tabular}{lccccc}
\hline Materials & Carboxylic $\left(\mathrm{meq} \mathrm{g}^{-1}\right)$ & Phenolic $\left(\mathrm{meq} \mathrm{g}^{-1}\right)$ & Lactonic $\left(\mathrm{meq} \mathrm{g}^{-1}\right)$ & Total acid $\left(\mathrm{meq} \mathrm{g}^{-1}\right)$ & ${\text { Total basic }\left(\mathrm{meq} \mathrm{g}^{-1}\right)}^{\text {ACPH }}$ \\
\hline ACPA & 1.23 & 1.75 & 0.00 & 2.98 & 3.18 \\
ACP & 2.65 & 0.11 & 0.00 & 2.76 & 3.17 \\
NIC & 1.34 & 1.36 & 0.00 & 2.70 & 3.17 \\
RM & 2.49 & 1.56 & 0.00 & 4.05 & 3.07 \\
\hline
\end{tabular}




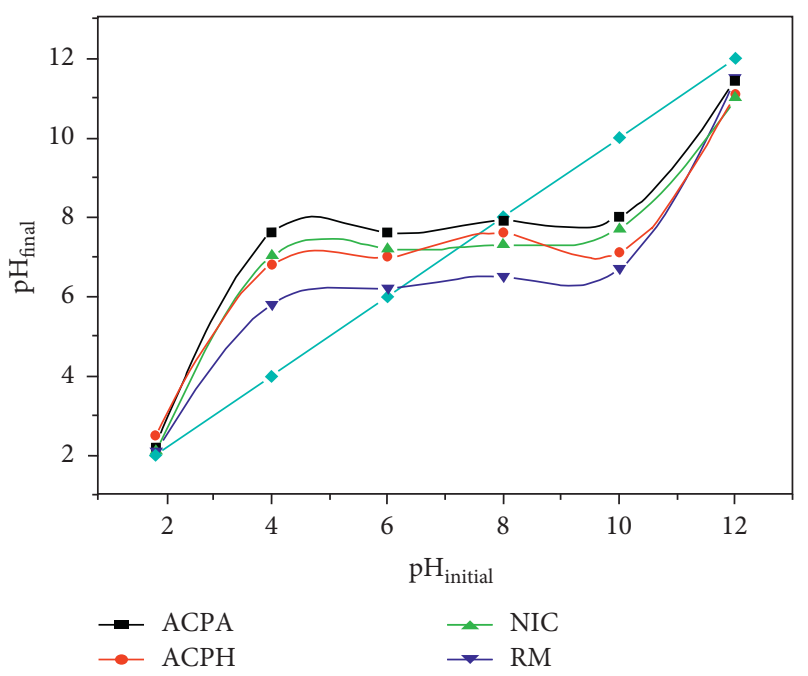

Figure 4: Determination of pHzpc of different adsorbents.

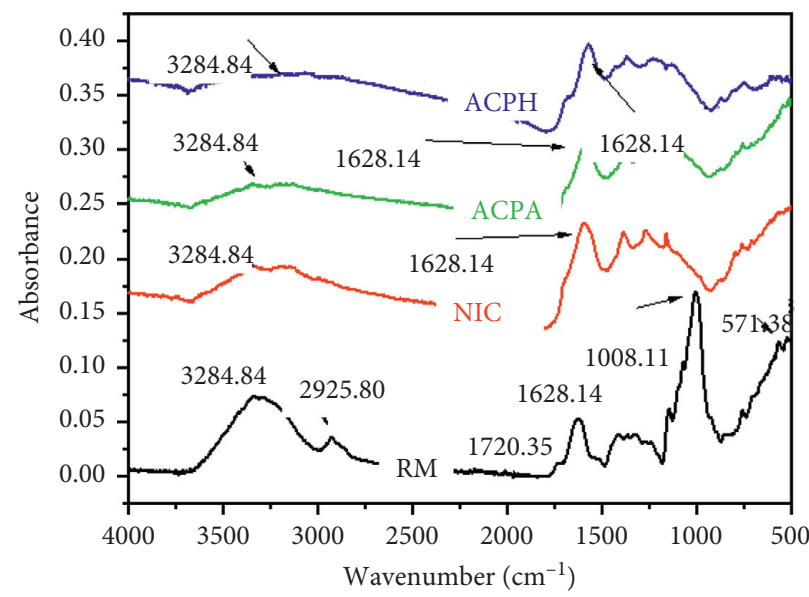

FIGURE 5: FT-IR spectra of the peelings of cassava tubers and their activated carbon.

TABLE 4: Wavenumbers and attributions of the principal bands in the FTIR spectra of peelings of cassava tubers and activated carbons (ACPH, ACPA, NIC, and RM).

\begin{tabular}{|c|c|c|c|c|c|}
\hline $\begin{array}{l}\text { Wavenumber } \\
\left(\mathrm{cm}^{-1}\right)\end{array}$ & Functional groups and chromophores & $\mathrm{ACPH}$ & ACPA & NIC & $\mathrm{RM}$ \\
\hline $3400-3200$ & $\begin{array}{c}\mathrm{O}-\mathrm{H} \text { stretching vibration, characteristic peak of carboxyls, phenols, alcohols, or water } \\
\text { absorbed }\end{array}$ & * & $*$ & $*$ & * \\
\hline $3000-2800$ & $\begin{array}{c}\mathrm{C}-\mathrm{H} \text { aliphatic stretching vibration of aromatic methoxyl groups or in methyl and } \\
\text { methylene side chains }\end{array}$ & & & & * \\
\hline 1720.35 & $\begin{array}{c}\mathrm{C}=\mathrm{O} \text { stretching vibration of the carbonyl group in ketones, aldehydes, lactones, or the } \\
\text { carboxyls groups }\end{array}$ & & & & $*$ \\
\hline 1628.14 & $\mathrm{C}=\mathrm{C}$ stretching variation in aromatic rings enhanced by polar functional groups & $*$ & * & $*$ & * \\
\hline 1008.11 & $\begin{array}{l}\text { C-O stretching vibration in carboxylic acids, alcohol, phenol, ether or the } \mathrm{P}=\mathrm{O} \text { bond in } \\
\text { phosphate esters, or still } \mathrm{O}-\mathrm{C} \text { bond in } \mathrm{P}-\mathrm{O}-\mathrm{C} \text { linkage and } \mathrm{P}=\mathrm{OOH}[27]\end{array}$ & & & & $*$ \\
\hline $900-400$ & $=\mathrm{C}-\mathrm{H}$ bending vibrations of the aromatic polynuclear systems & & & & $*$ \\
\hline
\end{tabular}

water molecules contained at the surface. We also note the disappearance of the band of asymmetrical (C-H) stretching vibration at $2925.80 \mathrm{~cm}^{-1}$ for the three activated carbons (ACPH, ACPA, and NIC). This indicates that activation significantly destroys part of the aliphatic and aromatic $\mathrm{C}-\mathrm{H}$ bond [29]. The bands located around $1628.14 \mathrm{~cm}^{-1}$ are attributed to the aromatic carbon-carbon double bonds $(\mathrm{C}=\mathrm{C})$. After activation, a significant reduction in absorption peak was observed for a series of complex bands around $1008.11 \mathrm{~cm}^{-1}$ for the precursor, which includes $\mathrm{C}-\mathrm{O}$ stretching vibration in carboxylic acids, alcohol, phenol, ether, or the $\mathrm{P}=\mathrm{O}$ bond in phosphate esters, or still $\mathrm{O}-\mathrm{C}$ bond 
in $\mathrm{P}-\mathrm{O}-\mathrm{C}$ linkage and $\mathrm{P}=\mathrm{OOH}$ [27]. From 900 to $400 \mathrm{~cm}^{-1}$, there are bands characteristic of aromatic rings.

5.4.4. Scanning Electron Microscopy (SEM). SEM micrographs of the precursor (Figure 6(a)), the untreated activated carbons (Figure 6(b)), the treated activated carbons by $\mathrm{H}_{3} \mathrm{PO}_{4}$ (Figure 6(c)), and $\mathrm{KOH}$ (Figure 6(d)), respectively, are presented in Figure 6 . We notice here that the precursor (a) has a surface with no visible pores before carbonization. After carbonization of precursor (Figures 6(b)-6(d)), we observe porous structures and rough textures of the surface. These pores resulted from the evaporation of the chemical reagent $\left(\mathrm{H}_{3} \mathrm{PO}_{4}\right.$ and $\left.\mathrm{KOH}\right)$ during carbonization, leaving the space previously occupied by the reagents.

\section{Adsorption Studies}

6.1. Effect of Contact Time. In order to determine the effect of contact time on the extent of adsorption, $0.1 \mathrm{~g}$ of the adsorbent was stirred with a $20 \mathrm{~mL}$ solution of nickel(II) ions of initial concentration of $200 \mathrm{mg} / \mathrm{L}$ for a time interval of 5-60 minutes for ACPH, ACPA, NIC, and RM. The experimental results obtained for the adsorption of nickel(II) ions during various contact times are illustrated in Figure 7. From the results, it can be observed that the adsorbed quantity of nickel(II) ions increased rapidly and attained maximum values at $51.81 \mathrm{mg} / \mathrm{g}$ for $\mathrm{ACPH}, 50.86 \mathrm{mg} / \mathrm{g}$ for ACPA, $47.74 \mathrm{mg} / \mathrm{g}$ for NIC, and $41.41 \mathrm{mg} / \mathrm{g}$ for RM after an equilibrium time of 40 minutes for the four samples. This can be explained by the fact that initially there are available free adsorption sites on the surface of the adsorbents for adsorption. Beyond this stage, one observes the progressive surface saturation of various materials studied. This saturation is due to the total occupation of the active sites at the surface of the adsorbents [18]. Results show a higher adsorption capacity of prepared activated carbon samples compared to the raw material.

6.2. Effect of the Initial $p H$. Figure 8 represents the effect of the initial $\mathrm{pH}$ of the solution on the adsorption of nickel(II) ions onto ACPH, ACPA, NIC, and RM using $200 \mathrm{mg} / \mathrm{L}$ initial nickel(II) concentration and $0.1 \mathrm{~g}$ of adsorbent. $\mathrm{pH}$ was varied between 2 and 8 within 40 minutes of contact time. Results show that adsorbed quantities of the nickel(II) ions increase gradually until maximum removal is attained at $\mathrm{pH}=4(51.81 \mathrm{mg} / \mathrm{g}$ for $\mathrm{ACPH}, 51.86 \mathrm{mg} / \mathrm{g}$ for ACPA, $48.85 \mathrm{mg} / \mathrm{g}$ for NIC, and $27.93 \mathrm{mg} / \mathrm{g}$ for RM) and decrease thereafter. At lower $\mathrm{pH}$ values, nickel(II) removal is inhibited because of the competition between hydrogen and nickel(II) ions for sorption sites [30]. The decrease in the adsorbed quantity beyond $\mathrm{pH}=4$ is due to the formation of a nickel hydroxide precipitate $\left(\mathrm{Ni}(\mathrm{OH})_{2}\right)$ in agreement with the work of [7].

The mechanism of the adsorption of $\mathrm{Ni}$ (II) ions from the aqueous solution by the activated carbons has been explained in terms of the surface chemistry of the carbons and the $\mathrm{pH}$ of the solution. In aqueous solutions, $\mathrm{Ni}$ (II) may exist as $\mathrm{Ni}^{2+}, \mathrm{Ni}(\mathrm{OH})^{+}, \mathrm{Ni}(\mathrm{OH})^{-}$, and $\mathrm{Ni}(\mathrm{OH})_{2}$ (as a precipitate): the acidic carbon-oxygen surface group on ionization produce $\mathrm{H}^{+}$and the negatively charged surface sites. However, the presence of nickel ions in the solution and the concentration of the negative site or the negative charge on the carbon surface are determined by the $\mathrm{pH}$ of the solution $[7,31]$.

At a low $\mathrm{pH}$ value ( $\mathrm{pH}$ below $\mathrm{pHzpc}$ ), the carbon surface has a positive charge because of low ionization of the surface groups and excessive protonation of the surface and creates repulsive interactions with the nickel cations leading to low adsorption. But at higher $\mathrm{pH}$ values $(\mathrm{pH}>\mathrm{pHzpc})$, the adsorption of $\mathrm{Ni}$ (II) increases as a result of a high degree of ionization of the surface acidic groups and the dominance of nickel cation in the solution phase that enhances the attractive interactions. At very high $\mathrm{pH}$ values, the dominant nickel ions in the solution are anionic complexes that produce repulsive interactions and decrease the adsorption $[7,31]$.

6.3. Effect of Adsorbent Dose. The influence of the adsorbent dose on the removal of nickel(II) ions from an aqueous solution was studied by varying its concentration from 0.1 to $0.6 \mathrm{~g}$. Figure 9 represents the influence of adsorbent dose on the adsorption of nickel(II) ions onto ACPH, ACPA, NIC, and $\mathrm{RM}$ using $200 \mathrm{mg} / \mathrm{L}$ initial nickel(II) concentration at $\mathrm{pH}=4$ for a contact time of 40 minutes. The adsorbed quantity decreased with increasing adsorbent masses. This is due to the fact that an increase in adsorbent dose leads to an agglomeration of particles which prevent the nickel(II) ions to approach the sites of adsorption and consequently a reduction in the quantity adsorbed per unit mass of adsorbent [32]. This can still be explained by the fact that during the process of adsorption, certain adsorption sites remain unsaturated [18].

6.4. Effect of the Initial Concentration of Nickel(II). Studies were performed with initial nickel(II) concentrations ranging from 110 to $210 \mathrm{mg} / \mathrm{L}$. $0.1 \mathrm{~g}$ of adsorbent and $\mathrm{pH}=4$ was used for the adsorption experiments. The experimental results of the effect of the initial nickel(II) concentration on the adsorption capacity are presented in Figure 10. It is obvious from this figure that nickel(II) adsorption increases with an increase in initial nickel(II) concentration because an increase in the initial concentration of nickel(II) ions brings about an increase in mass transfer from the aqueous phase to the solid phase. This can still be explained by the increasing driving force of the metal ions toward the active sites on the adsorbents [33].

\section{Adsorption Isotherms}

Adsorbate distribution between liquid and solid phases, solute-solution interaction, and knowledge of the adsorption capacity of adsorbent are described by isotherm models such as Langmuir, Freundlich, and Temkin models [34]. 


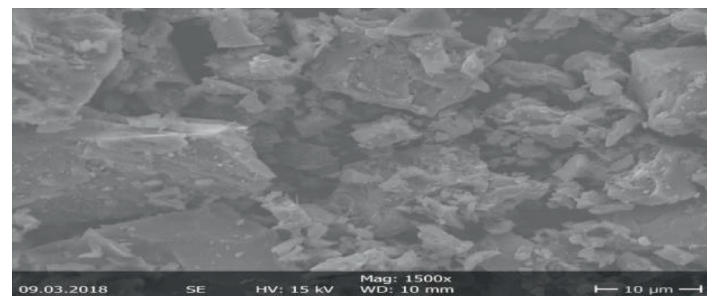

(a)

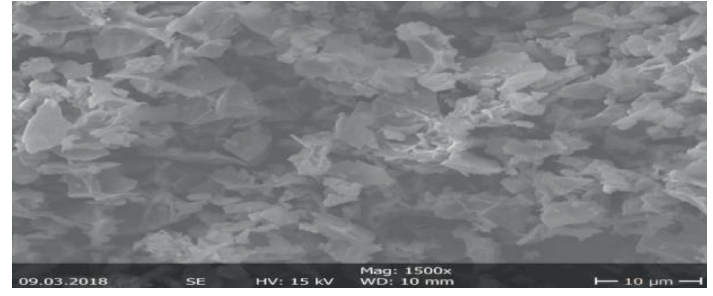

(c)

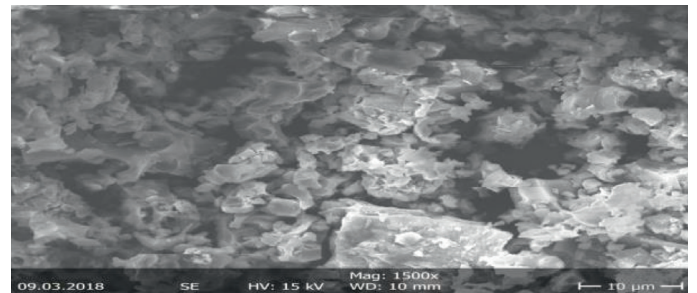

(b)

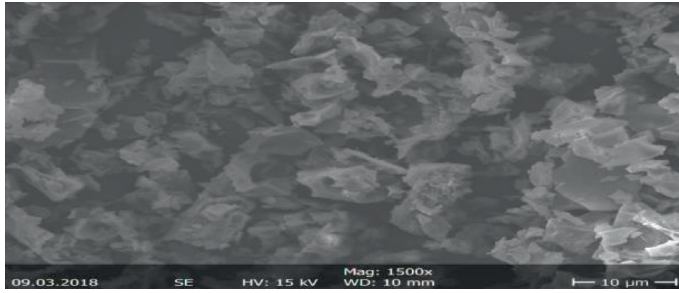

(d)

FIGURE 6: Morphology of samples: (a) precursor-RM, (b) NIC, (c) ACPA, and (d) ACPH.

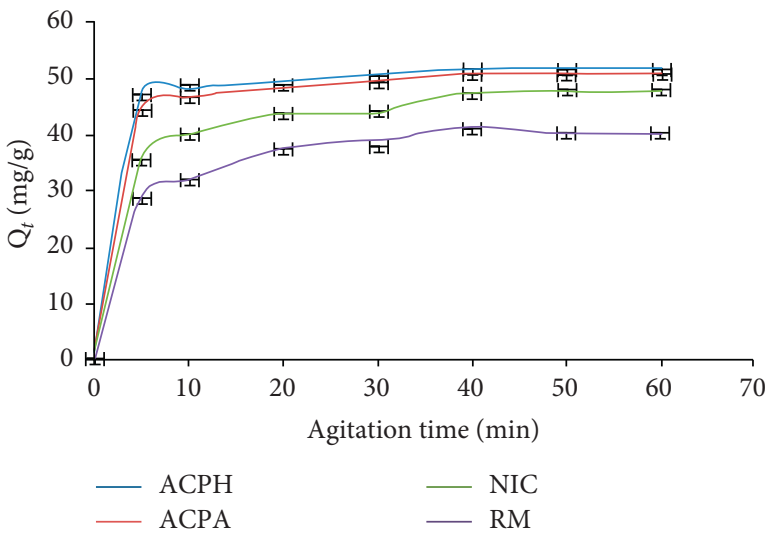

FIGURE 7: Effect of contact time on nickel(II) adsorption for ACPH, ACPA, NIC, and RM (volume $=20 \mathrm{~mL}, \mathrm{Co}=200 \mathrm{mg} / \mathrm{L}, \mathrm{pH}=4$, adsorbent dose $=0.1 \mathrm{~g}$, stirring rate $150 \mathrm{rpm}$ ).

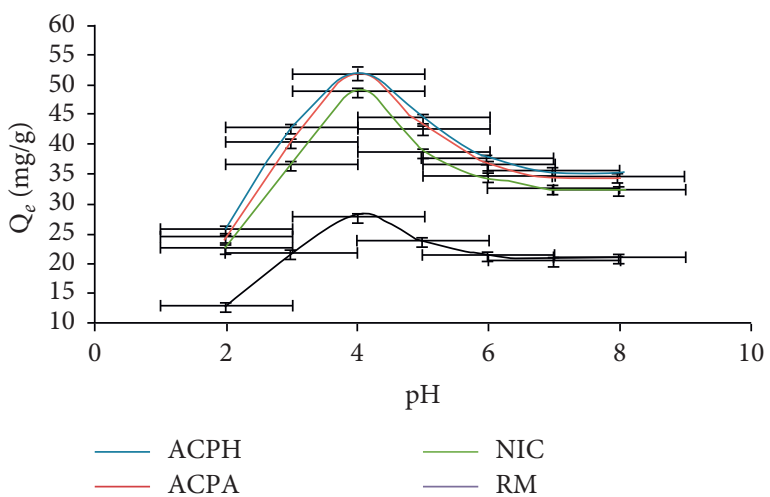

Figure 8: Effect of $\mathrm{pH}$ on nickel(II) adsorption for ACPH, ACPA, NIC, and RM (volume $=20 \mathrm{~mL}$, teq $=40 \mathrm{~min}, \mathrm{Co}=200 \mathrm{mg} / \mathrm{L}$, adsorbent dose $=0.1 \mathrm{~g}$, stirring rate $150 \mathrm{rpm})$.

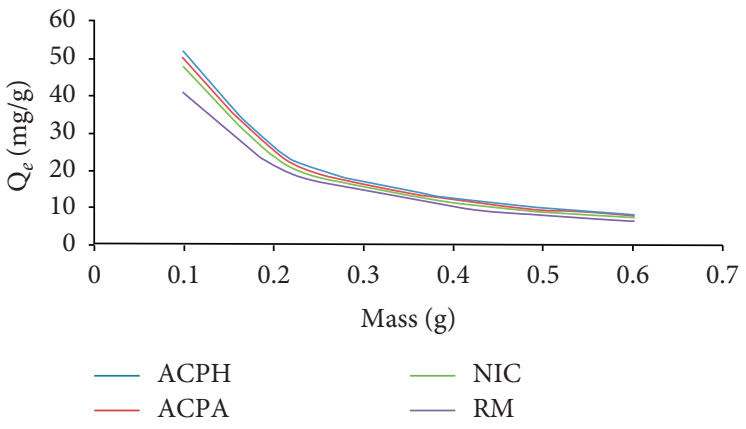

FIGURE 9: Effect of adsorbent mass on nickel(II) adsorption for $\mathrm{ACPH}, \mathrm{ACPA}, \mathrm{NIC}$, and RM $(v=20 \mathrm{~mL}, t=40 \mathrm{~min}, \mathrm{Co}=200 \mathrm{mg} / \mathrm{L}$, $\mathrm{pH}=4$, stirring velocity $150 \mathrm{rpm})$.

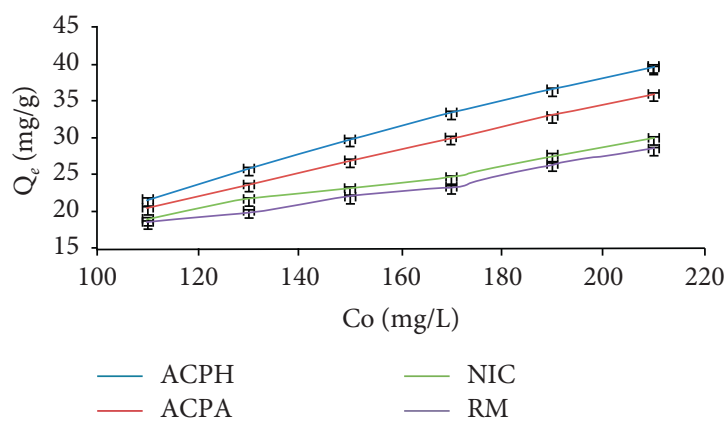

FIgURE 10: Effect of initial concentration on nickel(II) adsorption for ACPH, ACPA, NIC, and RM $(v=20 \mathrm{~mL}, t=40 \mathrm{~min}, \mathrm{pH}=4$, adsorbent dose $=0.1 \mathrm{~g}$, stirring velocity $150 \mathrm{rpm}$ ). 
7.1. Langmuir Adsorption Isotherm. The Langmuir model assumes that metal ion uptake occurs on a homogeneous surface by monolayer adsorption without any interaction between adsorbed ions, uniform energies of adsorption are involved, and there is no transmigration of adsorbate in the plane of the surface [35]. The linearized Langmuir isotherm equation is expressed as

$$
\frac{C_{e}}{Q_{e}}=\frac{1}{K_{L} Q_{m}}+\frac{C_{e}}{Q_{m}},
$$

where $K_{L}$ is the Langmuir adsorption constant $(\mathrm{L} / \mathrm{mg})$ which is related to the maximum sorption capacity and the adsorption energy, Ce is the equilibrium concentration $(\mathrm{mg} / \mathrm{L})$, $Q_{e}$ is the quantity adsorbed per gram of adsorbent at equilibrium $(\mathrm{mg} / \mathrm{g})$, and $Q_{m}(\mathrm{mg} / \mathrm{g})$ is an indicator of monolayer adsorption capacity. The efficiency of the Langmuir adsorption process is further assessed by (12):

$$
R_{L}=\frac{1}{1+K_{L} C_{\mathrm{o}}},
$$

where $R_{L}$ is a dimensionless constant referred to as separation factor, $K_{L}$ is the Langmuir constant related to the adsorption energy, and $C_{\mathrm{o}}$ is the initial solute concentration (mg/L). If $R_{L}>1$, adsorption is said to be unfavorable, $R_{L}=1$ for linear adsorption, $0<R_{L}<1$ for favorable adsorption, and $R_{L}=0$ for irreversible adsorption [36].

7.2. Freundlich Adsorption Isotherm. The Freundlich model assumes that the uptake of metal ions occurs on a heterogeneous surface by monolayer adsorption [37]. The linearized relation (11) is given as follows:

$$
\log Q_{e}=\log K_{F}+\left(\frac{1}{n}\right) \log C_{e},
$$

where $Q_{e}$ is the quantity of the solute adsorbed at equilibrium (adsorption density: mg of adsorbate per $g$ of adsorbent). $C_{e}$ is the concentration of adsorbate at equilibrium, $1 / n(\mathrm{mg} / \mathrm{L})$ is the adsorption intensity or the heterogeneity factor, and $K_{F}$ is the Freundlich constant related to the adsorption energy $\left(\mathrm{mol}^{2} / \mathrm{kJ}^{2}\right)$. The last two constants are dependent on temperature and the nature of sorbent and sorbate.

7.3. Temkin Adsorption Isotherm. It is expressed by the following linear relationship between the amount adsorbed $Q_{e}$, and concentration of the solution at equilibrium $C_{e}$ [38].

$$
Q_{e}=B_{T}\left(\ln K_{T}+\ln C_{e}\right) \text {, }
$$

where $K_{T}(\mathrm{~L} / \mathrm{g})$ is the Temkin isotherm constant (equilibrium binding constant), $B_{T}(\mathrm{~J} / \mathrm{mol})$ is a constant related to the heat of sorption, $R$ is the gas constant $\left(8.314 \times 10^{-3} \mathrm{~kJ} / \mathrm{mol} . \mathrm{K}\right)$, and $T$ is the absolute temperature $(\mathrm{K})$. This model takes into account the heterogeneity of the surface [38]. In order to find the most appropriate model for the nickel(II) adsorption, the data was fitted to each isotherm model.

Table 5 presents the calculated parameters of the different models from which we can be seen that only the
TABLE 5: Results of adsorption parameters for the different isotherm models.

\begin{tabular}{lccccc}
\hline Models & Constants & ACPH & ACPA & NIC & RM \\
\hline \multirow{4}{*}{ Langmuir isotherm } & $R^{2}$ & 0.995 & 0.982 & 0.966 & 0.947 \\
& $Q_{\max }(\mathrm{mg} / \mathrm{g})$ & 41.15 & 47.39 & 35.34 & 34.48 \\
& $K_{L}(\mathrm{~L} / \mathrm{mg})$ & 1.748 & 0.095 & 0.067 & 0.053 \\
& $R_{L}$ & 0.003 & 0.050 & 0.070 & 0.086 \\
& $\mathrm{RMSE}$ & 5.907 & 1.412 & 1.654 & 1.917 \\
\hline \multirow{4}{*}{ Freundlich } & $R^{2}$ & 0.632 & 0.988 & 0.933 & 0.891 \\
isotherm & $1 / n$ & 0.142 & 0.383 & 0.293 & 0.297 \\
& $K(L / g)$ & 27.56 & 9.645 & 8.560 & 7.414 \\
& $\mathrm{RMSE}$ & 3.964 & 0.642 & 1.242 & 1.838 \\
\hline \multirow{4}{*}{ Temkin isotherm } & $R^{2}$ & 0.707 & 0.969 & 0.903 & 0.853 \\
& $K_{\mathrm{T}}(L / \mathrm{g})$ & 3.431 & 0.943 & 0.981 & 0.876 \\
& $\Delta \mathrm{Q}(\mathrm{KJ} / \mathrm{mol})$ & 22.65 & 11.86 & 12.59 & 12.62 \\
& $\mathrm{RMSE}$ & 38.69 & 34.70 & 29.29 & 27.92 \\
\hline
\end{tabular}

Langmuir isotherm model $\left(R^{2}=0.995,0.982,0.966\right.$, and 0.947 for ACPH, ACPA, NIC, and RM, respectively) best fits the experimental data. Adsorption of nickel(II) ions at $27^{\circ} \mathrm{C}$ according to the Langmuir model was found to be equal to $41.15,47.39,35.34$, and $34.48 \mathrm{mg} / \mathrm{g}$ for ACPH, ACPA, NIC, and RM samples, respectively. The shape of the Langmuir isotherm was characterized by the dimensionless constant or separation term $\left(R_{L}\right)$. In this investigation, the equilibrium parameter was found to be in the range $0<R_{L}<1$ as shown in Table 5 . This indicates that the sorption process was very favorable and that the adsorbent employed exhibits good adsorption potentials. From the Freundlich model, the values of the constants $1 / n$ are lower than unity for all four materials and proved that adsorption is favorable in all cases studied. These values show that the activated carbon ACPA presents a better affinity for the nickel(II) ions compared to the three other materials. The Temkin model provided various heats of adsorption brought into play at the time of the various interactions. Taking into account the results presented in Table 5, one notes that these values of heats of adsorption $(\triangle \mathrm{Q})$ of the four materials ACPH, ACPA, NIC, and $\mathrm{RM}$ are positive $(\Delta Q>0)$. This means that the adsorption process is exothermic (physical adsorption). The values of Temkin constants $A_{T}$ and $B_{T}$ as well as the correlation coefficients are listed in Table 5. Isotherms for Langmuir, Freundlich, and Temkin models are found in supplementary materials (Figures S1-S3, respectively).

\section{Kinetics of Adsorption Process}

Four kinetic models have been studied in describing the adsorption phenomenon of nickel(II) ions onto the four material samples studied herein: pseudo-first-order, pseudosecond-order, Elovich, and intraparticle diffusion models.

8.1. Pseudo-First-Order Model. Kinetic parameters for the adsorption process were studied for contact times ranging between 5 and 60 minutes by monitoring the quantity of nickel(II)) adsorbed as a function of time. The data were then regressed against the Lagergren equation (13), which represents a first-order kinetic equation [39]. 
TABLE 6: Results of adsorption parameters for the different kinetic models.

\begin{tabular}{|c|c|c|c|c|c|}
\hline Model & Constants & $\mathrm{ACPH}$ & ACPA & NIC & $\mathrm{RM}$ \\
\hline \multirow{4}{*}{ Pseudo-first-order } & $R^{2}$ & 0.978 & 0.985 & 0.917 & 0.897 \\
\hline & $K_{1}\left(\min ^{-1}\right)$ & 0.055 & 0.062 & 0.050 & 0.073 \\
\hline & $Q_{e}(\mathrm{mg} / \mathrm{g})$ & 6.459 & 8.049 & 13.62 & 16.11 \\
\hline & RMSE & 53.89 & 50.77 & 41.02 & 29.23 \\
\hline \multirow{6}{*}{ Pseudo-second-order } & $R^{2}$ & 0.999 & 0.999 & 0.999 & 0.999 \\
\hline & $\mathrm{h}(\mathrm{mg} / \mathrm{g} \cdot \mathrm{min})$ & 57.06 & 48.99 & 19.70 & 17.11 \\
\hline & $t_{1 / 2}(\min )$ & 0.921 & 1.058 & 2.535 & 2.475 \\
\hline & $K_{2}$ (g/mg.min) & 0.021 & 0.018 & 0.008 & 0.010 \\
\hline & $Q_{e}(\mathrm{mg} / \mathrm{g})$ & 52.63 & 51.81 & 50.00 & 42.37 \\
\hline & RMSE & 1.242 & 1.242 & 1.380 & 1.175 \\
\hline \multirow{8}{*}{ Intraparticle diffusion } & $R^{2}$ & 0.996 & 0.972 & 0.974 & 0.996 \\
\hline & $K_{\mathrm{id} 1}\left(\min ^{-1}\right)$ & 1.005 & 1.857 & 3.627 & 3.970 \\
\hline & $\mathrm{C}_{1}(\mathrm{mg} / \mathrm{g})$ & 44.88 & 40.46 & 27.92 & 19.81 \\
\hline & RMSE & 0.484 & 2.353 & 4.931 & 6.063 \\
\hline & $R^{2}$ & 0.646 & 0.627 & 0.679 & 0.094 \\
\hline & $K_{\mathrm{id} 2}\left(\min ^{-1}\right)$ & 0.476 & 0.509 & 1.450 & 0.291 \\
\hline & $C_{2}(\mathrm{mg} / \mathrm{g})$ & 48.36 & 47.09 & 36.96 & 38.32 \\
\hline & RMSE & 1.418 & 1.985 & 2.319 & 5.652 \\
\hline \multirow{4}{*}{ Elovich } & $R^{2}$ & 0.970 & 0.977 & 0.971 & 0.934 \\
\hline & $\beta(\mathrm{g} / \mathrm{mg})$ & 0.475 & 0.373 & 0.198 & 0.197 \\
\hline & $\alpha(\mathrm{mg} / \mathrm{g} \mathrm{min})$ & $1.99 \times 10^{9}$ & $9.24 \times 10^{6}$ & $1.30 \times 10^{3}$ & $3.28 \times 10^{2}$ \\
\hline & RMSE & 0.294 & 0.319 & 0.683 & 1.057 \\
\hline
\end{tabular}

$$
\operatorname{Ln}\left(Q_{e}-Q_{t}\right)=\operatorname{Ln} Q_{e}-K_{t} t,
$$

where $k_{1}$ is the pseudo-first-order rate constant $\left(\mathrm{min}^{-1}\right) ; Q_{e}$ and $Q_{t}$ are the adsorption capacities at equilibrium and at a given time $t$ and are expressed in $(\mathrm{mg} / \mathrm{g})$.

8.2. Pseudo-Second-Order Model. The linearized pseudosecond-order chemisorption kinetic model, equation (14) [40], has been appropriately utilized in experiments involving the adsorption of organics and heavy metals on activated carbon.

$$
\frac{t}{Q_{t}}=\frac{1}{K_{2} Q_{e}^{2}}+\frac{t}{Q_{e}}
$$

where $K_{2}$ is the pseudo-second-order rate constant $\left(\mathrm{mg} \cdot \mathrm{g}^{-1} \cdot \mathrm{min}^{-1}\right)$.

8.3. Elovich Model. The linearized Elovich equation is generally expressed as

$$
Q_{t}=\left(\frac{1}{\beta}\right) \ln (\alpha \beta)+\left(\frac{1}{\beta}\right) \ln t,
$$

where $\alpha$ is the initial sorption rate ( $\mathrm{mg} / \mathrm{g} \min )$ and $\beta$ is the desorption rate constant $(\mathrm{g} / \mathrm{mg})$ during any one experiment. These constants will be obtained from the relation $q_{t}=f(\ln t)[41]$.

8.4. Intraparticle Diffusion Model. The rate constants of intraparticle diffusion $\left(K_{\mathrm{id}}\right)$ at different nickel(II) ion concentrations were determined using the following linearized equation:

$$
q_{t}=K_{\mathrm{id}} t^{1 / 2}+C,
$$

where $q_{t}$ is the amount of nickel(II) sorbed at time $t . K_{\mathrm{id}}$ is the intraparticle diffusion constant $\left(\mathrm{mg} \cdot \mathrm{g}^{-1} \cdot \mathrm{min}^{-1 / 2}\right)$. When intraparticle diffusion plays a significant role in controlling the kinetics of the sorption process, straight-line plots through the origin are obtained and their slopes give the rate constant, $k_{\text {id }}$.

The results of kinetic studies (Table 6) indicate that the adsorption process follows the second-order rate equation for the four adsorbents with correlation coefficient $R^{2}=0.999$ for ACPH, ACPA, NIC, and RM. This implies that chemisorption is the limiting step of the process [41]. By comparison, the values of $Q_{e}$ determined from this model, which stand as $52.63 \mathrm{mg} / \mathrm{g}$ for ACPH, $51.81 \mathrm{mg} / \mathrm{g}$ for ACPA, $50.00 \mathrm{mg} / \mathrm{g}$ for NIC, and $42.37 \mathrm{mg} / \mathrm{g}$ for RM, are very close to their experimental analogs. This confirms once more that ACPH and ACPA performed better in nickel(II) uptake compared to the two others. Initial rates show that the kinetics of adsorption of the pollutant is faster on the surface of ACPH than to ACPA, NIC, and RM. The half-life of the pseudo-second-order reaction shows that adsorption kinetics of the nickel(II) ions is faster on the surface of the NIC compared to the other materials (ACPH, ACPA, and RM).

Results obtained from intraparticle diffusion model (obtained via $Q_{t}=f\left(\mathrm{t}^{1 / 2}\right)$ ) are graphs with two linear portions each (Figure 11) indicative of an adsorption process taking place in two steps for all four adsorbents. The first portion is characterized by rapid or fast diffusion of nickel(II) from the external surface toward the macropores of the adsorbents also known as macroporous diffusion [42]. This portion is also characterized by higher diffusion constants, $K_{\mathrm{dil}}$. The second portion corresponds to very slow diffusion with slow constant values of $K_{\mathrm{di} 2}$ showing saturation of macropores by 


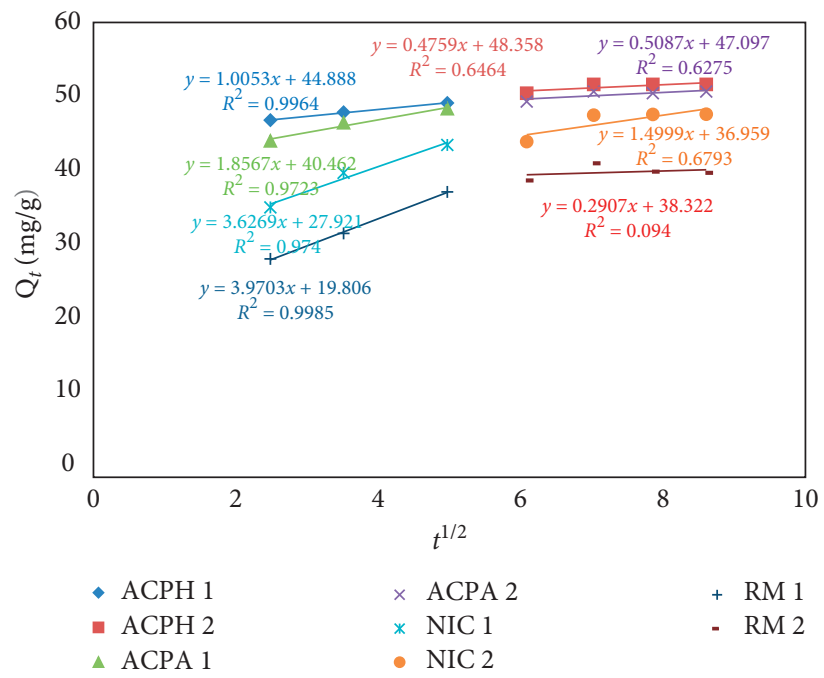

FIGURE 11: Intraparticle diffusion model for the adsorption of nickel(II) ions onto prepared activated carbon (ACPH, ACPA, and NIC) and raw material, RM.

TABLE 7: Comparison of adsorption capacity $\left(\mathrm{Ni}^{2+}\right.$ ions) of activated carbons (adsorbents).

\begin{tabular}{lcc}
\hline Adsorbents & Adsorption capacity $(\mathrm{mg} / \mathrm{g})$ & References \\
\hline Mosambi fruit peelings & 29.41 & {$[22]$} \\
Cajanus cajan L. Millsp seed shell activated carbons & 29.60 & {$[30]$} \\
Activated carbon from artichoke & 49.02 & {$[43]$} \\
Modified holly sawdust & 22.47 & {$[45]$} \\
Activated carbon from peelings of cassava tubers & 46.53 & Present study \\
\hline
\end{tabular}

nickel ions. This step is called internal diffusion because diffusion takes place in the micropores [43]. It is obvious here that intraparticle diffusion model does not govern the adsorption process since the curves do not pass through the origin. Figures of the pseudo-first-order, pseudo-secondorder, and Elovich models are found in supplementary materials (Figures S4-S6, respectively). The values of all the model parameters and the correlation coefficients are presented in Table 6.

Our results on the adsorption capacity of studied activated samples have been compared with some results from the literature $[22,30,44,45]$ (see Table 7). We observe that activated carbons prepared from cassava tuber peelings (this study) offer better adsorption capacities for $\mathrm{Ni}$ (II) ions (adsorbate) and thereby constitute low-cost biomass for the depollution of nickel ions in an aqueous solution.

\section{Conclusion}

This work aimed at the removal of nickel(II) ions from an aqueous solution by batch adsorption experiments onto activated carbon from the peelings of cassava tubers $(\mathrm{ACPH}$, ACPA, and NIC). Best values of iodine indices were obtained at $400^{\circ} \mathrm{C}$ (pyrolysis temperature) for materials obtained via impregnation ratios of $2: 1$ and $1: 1$ for ACPH and ACPA, respectively. The functional groups on the surface of the adsorbents were characterized by chemical analysis of activated samples by the Boehm method and FTIR analysis.
Elemental analysis of three activated carbon samples (ACPH, ACPA, and NIC) revealed a higher carbon content for activated materials compared to the precursors. SEM imaging techniques showed microporous structures. Equilibrium studies showed that the Langmuir model best described the adsorption process with the best correlation coefficient close to unity, therefore implying monolayer adsorption on a homogeneous surface. Kinetic study of nickel(II) adsorption showed that the process is controlled by the pseudo-second-order model with correlation coefficient $R^{2}=0.999$ for ACPH, ACPA, NIC, and RM, respectively. This work has portrayed that activated carbons from cassava peelings can serve as effective low-cost agricultural materials for the treatment of water contaminated by nickel(II) ions.

\section{Data Availability}

The data used to support the findings of this study are available from the corresponding author upon request.

\section{Conflicts of Interest}

The authors declare that they have no conflicts of interest.

\section{Acknowledgments}

The authors are thankful to the Government of Cameroon for research modernization grants to researchers of higher 
education. The authors also acknowledge the material assistance of the Nutrition and Animal Food Laboratory of the University of Dschang and the Analytical Chemistry Laboratory of the University of Yaoundé I, Cameroon. Many thanks are expressed to Numbonui Stanley Tasheh (Department of Chemistry, Faculty of Science, University of Dschang, Cameroon) for his valuable assistance in language editing, proofreading, and editing of the figures.

\section{Supplementary Materials}

Table S1: variations of impregnation ratios, times, rate of heating, and the temperatures of carbonization. Figure S1: Langmuir isotherm for the adsorption of nickel(II) ions onto activated carbon prepared (ACPH, ACPA, and NIC) and raw material (RM). Figure S2: Freundlich isotherm for the adsorption of nickel(II) ions onto activated carbon prepared (ACPH, ACPA, and NIC) and raw material (RM). Figure S3: Temkin isotherm for the adsorption of nickel(II) ions onto activated carbon prepared $(\mathrm{ACPH}, \mathrm{ACPA}$, and NIC) and raw material (RM). Figure S4: a first-order model for the adsorption of nickel(II) ions onto activated carbon prepared (ACPH, ACPA, and NIC) and raw material (RM). Figure S5: a second-order model for the adsorption of nickel(II) ions onto activated carbon prepared (ACPH, ACPA, and NIC) and raw material (RM). Figure S6: Elovich model for the adsorption of nickel(II) ions onto activated carbon prepared (ACPH, ACPA, and NIC) and raw material (RM). (Supplementary Materials)

\section{References}

[1] B. Thouraya, V. Isabel, and O. Abdelmottaleb, "Comparative study of bivalent cationic metals adsorption $\mathrm{Pb}(\mathrm{II}), \mathrm{Cd}(\mathrm{II})$, $\mathrm{Ni}$ (II) and $\mathrm{Cu}(\mathrm{II})$ on olive stones chemically activated carbon," Journal of Chemical Engineering and Process Technology, vol. 4, pp. 2-7, 2013.

[2] M. T. Amin, A. A. Alazba, and M. Shafiq, "Comparative removal of lead and nickel ions onto nanofibrous sheet of activated polyacrylonitrile in batch adsorption and application of conventional kinetic and isotherm models," Membranes, vol. 11, pp. 1-16, 2021.

[3] S. B. Olugbenga, A. A. Kayode, U. B. Olayinka, and O. L. Ibrahim, "Sequestering Nickel (II) ions from aqueous solutions using various adsorbents," Journal of Analytical Environmental Chemistry, vol. 15, pp. 1-7, 2014.

[4] E. B. Mervette and M. A. Abdel-Moneim, "Adsorption kinetics of Nickel (II) onto activated carbon prepared from natural adsorbent rice husk," International Journal of Technology Enhancements and Emerging Engineering Research, vol. 2, pp. 145-148, 2014.

[5] E. V. Liakos, M. Mone, D. A. Lambropoulou, D. N. Bikiaris, and G. Z. Kyzas, "Adsorption Evaluation for the removal of nickel, mercury, and barium ions from single-component and mixtures of aqueous solutions by using an optimized biobased chitosan derivative," Polymers, vol. 13, pp. 1-20, 2021.

[6] V. R. Kinhikar, "Removal of nickel (II) from aqueous solutions by adsorption with Granular activated carbon (GAC)," Research Journal of Chemical Sciences, vol. 2, pp. 6-11, 2012.

[7] J. T. Nwabanne and P. K. Igbokwe, "Kinetics and equilibrium modeling of nickel adsorption by cassava Peel," Journal of Engineering and Applied Sciences, vol. 3, pp. 829-834, 2008.
[8] J. A. Muthanna, "Preparation of activated carbons from date stones by chemical activation method using $\mathrm{FeCl}_{3}$ and $\mathrm{ZnCl}_{2}$ as activating agents," Journal of Engineering, vol. 17, no. 4, pp. 1007-1022, 2011.

[9] A. Kannan and S. Thambidurai, "Comparative studies on the removal of nickel (II) from aqueous solution by using carbon derived from palmyra palm fruit seeds and commercial activated carbon," International Journal of Science and Technology, vol. 1, no. 1, pp. 93-107, 2008.

[10] E. Bernard, A. Jimoh, and J. O. Odigure, "Heavy metals removal from industrial wastewater by activated carbon prepared from coconut Shell," Research Journal of Chemical Sciences, vol. 3, pp. 3-9, 2013.

[11] A. A. Magda, M. B. Dawy, and A. A. Serage, "Efficient removal of phenol from water samples using sugarcane bagasse based activated carbon," Journal of Analytical and Bioanalytical Techniques, vol. 5, pp. 1-12, 2014.

[12] I. Ali, M. Asim, and T. A. Khan, "Low cost adsorbents for the removal of organic pollutants from wastewater," Journal of Environmental Management, vol. 113, pp. 170-183, 2012.

[13] L. G. Aajish, J. Thirumal, and D. J. Thirumal, "Preparation and characterization of activated carbon derived from waste materials and its application in the removal of fluoride from ground water," IOSR Journal of Environmental Science, Toxicology and Food Technology, vol. 8, no. 5, pp. 28-33, 2014.

[14] A. Mohammad and Z. Bahreini, "Preparation of carbonaceous Adsorbent from plant of calotropis gigantea by thermochemical activation process and its adsorption behavior for removal of Methylene Blue," World Applied Sciences Journal, vol. 11, pp. 263-268, 2010.

[15] P. Sugumaran, S. V. Priya, P. Ravichandran, and S. Seshadri, "Production and characterization of activated carbon from banana empty fruit bunch and delonix regia fruit pod," Journal of Sustainable Energy and Environment, vol. 3, pp. 125-132, 2012.

[16] D. L. Ajifack, J. N. Ghogomu, J. N. Ndi, and J. M. Ketcha, "Dynamics and equilibrium studies of the adsorption of $\mathrm{Cu}(\mathrm{II})$ from aqueous solutions by activated Hibiscus Sabdariffa. L. Stalk Biomass," International Journal of Engineering Research and Technology, vol. 4, pp. 655-664, 2015.

[17] O. A. Ekpete and M. J. Horsfall, "Preparation and characterization of activated carbon derived from fluted pumpkin stem waste (Telfairia occidentalis Hook F)," Research Journal of Chemical Sciences, vol. 1, pp. 10-17, 2011.

[18] S. M. Rajeshwar, Y. P. Amar, P. P. Bhadra, and P. R. Raja, "Preparation and characterization of activated carbon from Lapsi (choerospondias axillaris) seed stone by chemical activation with phosphoric acid," Research Journal of Chemical Sciences, vol. 2, pp. 80-86, 2012.

[19] P. Chubaakum, K. Daniel, S. R. Kaza, L. G. Rajib, and andS. Dipak, "Synthesis and characterization of activated carbon from the biowaste of the plant Manihot esculenta," Chemical Science Transactions, vol. 4, pp. 59-68, 2015.

[20] A. Reffas, "Etude de l'adsorption de colorants organiques (rouge nylosan et bleu de méthylene) sur des charbons actifs préparés à partir du marc de café," Thèse de Doctorat Université Mentouri-Constantine, Constantine, Algérie, 2010.

[21] D. Ajifack, J. Ghogomu, T. Noufame, J. Ndi, and J. Ketcha, "Adsorption of $\mathrm{Cu}$ (II) ions from aqueous solution onto chemically prepared activated carbon from theobroma cacoa," British Journal of Applied Science \& Technology, vol. 4, no. 36, pp. 5021-5044, 2014. 
[22] K. R. Hema, "Comparative studies of isotherm and kinetics on the adsorption of $\mathrm{Cr}(\mathrm{VI})$ and $\mathrm{Ni}(\mathrm{II})$ from aqueous solutions by powder of Mosambi fruit peelings," International Research Journal of Pure and Applied Chemistry, vol. 4, pp. 26-45, 2014.

[23] H. Mahdi, R. Mohammad, and G. McKay, "Equilibrium twoparameter isotherms of acid dyes sorption by activated carbons: study of residual errors," Chemical Engineering Journal, vol. 160, pp. 408-416, 2010.

[24] I. Ozdemir, M. Şahin, R. Orhan, and M. Erdem, "Preparation and characterization of activated carbon from Grape stalk by zinc chloride activation," Fuel Processing Technology, vol. 125, pp. 200-206, 2014.

[25] T. Khadiran, M. Z. Hussein, Z. Zainal, and R. Rusli, “Textural and chemical properties of activated carbon prepared from tropical peat soil by chemical activation method," BioResources, vol. 10, pp. 986-1007, 2015.

[26] T. Ibrahim, B. L. Moctar, G. Djaneye-Boundjou, K. S. Doni, and P. Nambo, "Optimisation du procédé de préparation des charbons actifs par voie chimique $\left(\mathrm{H}_{3} \mathrm{PO}_{4}\right)$ à partir des tourteaux de Karité et des tourteaux de Coton," International Journal of Biological and Chemical Sciences, vol. 6, pp. 461478, 2012.

[27] A. M. Puziy, O. I. Poddubnaya, A. Martínez-Alonso, F. Suárez-García, and J. M. D. Tascón, "Surface chemistry of phosphorus-containing carbons of lignocellulosic origin," Carbon, vol. 43, no. 14, pp. 2857-2868, 2005.

[28] N. J. Ndi, M. J. Ketcha, G. S. Anagho, N. J. Ghogomu, and E. P. D. Belibi, "Physical and chemical characteristics of activated carbon prepared by pyrolysis of chemically treated Cola nut (cola acuminata) shells wastes and its ability to adsorb organics," International Journal of Advanced Chemical Technology, vol. 3, pp. 1-13, 2014.

[29] R. H. Hesas, N. A. Arami, W. M. W. Daud, and J. N. Sahu, "Preparation and characterization of activated carbon from apple waste by microware-assisted phosphoric acid activation: application in methylene blue adsorption," BioResources, vol. 8, pp. 2950-2966, 2013.

[30] P. Thamilarasu, P. Sivakumar, and K. Karunakaran, "Removal of $\mathrm{Ni}$ (II) from aqueous solution by adsorption onto Cajanus cajan L Milsp seed shell activated carbons," Indian Journal of Chemical Technology, vol. 18, pp. 414-420, 2011.

[31] R. C. Bansal and M. Goyal, Activated Carbon Adsorption, Taylor and Francis group, New York, NY, USA, 2005.

[32] F. Sakr, A. Sennaoui, M. Elouardi, M. Tamimi, and A. Assabbane, "Adsorption study of Methylene Blue on biomaterial using cactus," Journal of Materials and Environmental Science, vol. 6, pp. 397-406, 2015.

[33] H. Kasaini, P. T. Kekana, A. A. Saghti, and K. Bolton, “Adsorption characteristics of cobalt and nickel on oxalate-treated activated carbons in sulphate media," World Academy of Science, Engineering and Technology, vol. 76, pp. 707-721, 2013.

[34] P. S. Kumar and K. Kirthika, "Equilibrium and kinetic study of adsorption of nickel from aqueous solution onto bael tree leaf powder," Journal of Engineering Science and Technology, vol. 4, pp. 351-363, 2009.

[35] C. P. Nanseu-Njiki, G. K. Dedzo, and E. Ngameni, "Study of the removal of paraquat from aqueous solution by biosorption onto Ayous (Triplochiton schleroxylon) sawdust," Journal of Hazardous Materials, vol. 179, no. 1-3, pp. 63-71, 2010.

[36] A. O. Dada, A. P. Olalekan, A. M. Olatunya, and O. Dada, "Langmuir, Freundlich, Temkin and Dubinin-Radushkevich Isotherms studies of equilibrium sorption of $\mathrm{Zn}^{2+}$ unto phosphoric acid modified rice husk," IOSR Journal of Applied Chemistry, vol. 3, pp. 38-45, 2012.

[37] J. N. Ndi and M. J. Ketcha, "The adsorption efficiency of chemically prepared activated carbon from cola nut shells by $\mathrm{ZnCl}_{2}$ on methylene blue," Journal of Chemistry, vol. 2013, Article ID 469170, 7 pages, 2013.

[38] J. Ghogomu, T. D. Noufame, M. J. Ketcha, and N. J. Ndi, "Removal of $\mathrm{Pb}(\mathrm{II})$ ions from aqueous solutions by kaolinite and metakaolinite materials," British Journal of Applied Science \& Technology, vol. 3, no. 4, pp. 942-961, 2013.

[39] Y. S. Ho, "Citation review of Lagergren kinetic rate equation on adsorption reactions," Scientometrics, vol. 59, pp. 171-177, 2004.

[40] Y. Ho, "Review of second-order models for adsorption systems," Journal of Hazardous Materials, vol. 136, no. 3, pp. 681-689, 2006.

[41] O. S. Amodu, T. V. Ojumu, S. K. Ntwampe, and O. S. Ayanda, "Rapid adsorption of crystal violet onto magnetic zeolite synthesized from fly ash and magnetite nanoparticles," Journal of Encapsulation and Adsorption Sciences, vol. 5, no. 4, pp. 191-203, 2015.

[42] P. Ruchi, N. G. Ansari, R. P. Lakhan, and R. M. Chandra, "Removal of $\mathrm{Cd}(\mathrm{II})$ ions from simulated wastewater by $\mathrm{HCl}$ modified cucumis sativus peel: equilibrium and Kinetic study," Air, Soil and Water Research, vol. 7, pp. 93-101, 2014.

[43] A. S. Ahmed, A. M. A. Ahmed, M. A. Mohamed et al., "An efficient biosorption of direct dyes from industrial wastewaters using pretreated sugarcane bagasse," Energy and Environmental Engineering, vol. 1, pp. 10-16, 2013.

[44] R. A. Adnan, "Preparation of activated carbon from artichoke stem by $\mathrm{ZnCl}_{2}$ activation: application in nickel(II) adsorption from aqueous solution," M.S. thesis, Eastern Mediterranean University, Gazimağusa, North Cyprus, 2014.

[45] M. R. Samarghandi, S. Azizian, M. S. Shirzad, S. J. Jafari, and S. Rahimi, "Removal of divalent nickel from aqueous solutions by adsorption onto modified holly sawdust: equilibrium and kinetics," Iran Journal of Environmental Health Science and Engineering, vol. 8, pp. 181-188, 2011. 